\title{
Techniques for the Stabilization and Assessment of Treated Copper-, Chromium-, and Arsenic-contaminated Soil
}

Remediation mainly based on excavation and burial of the contaminated soil is impractical with regard to the large numbers of sites identified as being in need of remediation. Therefore, alternative methods are needed for brownfield remediation. This study was conducted to assess a chemical stabilization procedure of CCA-contaminated soil using iron (Fe)-containing blaster sand (BS) or oxygen-scarfing granulate (OSG). The stabilization technique was assessed with regard to the feasibility of mixing ameliorants at an industrial scale and the efficiency of the stabilization under different redox conditions. The stability was investigated under natural conditions in 1- $\mathrm{m}^{3}$ lysimeters in a field experiment, and the effect of redox conditions was assessed in a laboratory experiment $(10 \mathrm{~L})$. The treatments with high additions of ameliorant ( $8 \%$ and 17\%) were more successful in both the laboratory and field experiments, even though there was enough $\mathrm{Fe}$ on a stochiometric basis even at the lowest addition rates $(0.1 \%$ and $1 \%)$. The particle size of the $\mathrm{Fe}$ and the mixing influenced the stabilization efficiency. The development of anaerobic conditions, simulated by water saturation, increases the fraction of arsenic (As $\left.{ }^{\prime \prime \prime}\right)$ and, consequently, As mobility. The use of high concentrations of OSG under aerobic conditions increased the concentrations of nickel $(\mathrm{Ni})$ and copper $(\mathrm{Cu})$ in the pore water. However, under anaerobic conditions, it decreased the As leaching compared with the untreated soil, and $\mathrm{Ni}$ and $\mathrm{Cu}$ leaching was not critical. The final destination of the treated soil should govern the amendment choice, that is, an OSG concentration of approximately $10 \%$ may be suitable if the soil is to be landfilled under anaerobic conditions. Alternatively, the soil mixed with $1 \%$ BS could be kept under aerobic conditions in a landfill cover or in situ at a brownfield site. In addition, the treatment with BS appeared to produce better effects in the long term than treatment with OSG.

\section{INTRODUCTION}

A commonly applied practice in attempts to remediate brownfield sites contaminated with trace elements is landfilling, that is, excavation and burial of the contaminated soil, in order to restrict the pollutants to a controlled area. However, this approach is impractical when large numbers of sites are identified as being in need of remediation. Furthermore, the pollutants are retained in the soil matrix, and there are consequent risks that they will be mobilized, sometimes unpredictably, in the future (1). To address this potential problem at sites that are not severely contaminated, a strategy that has been advocated recently is to apply a pretreatment that chemically stabilizes the metals $(2,3)$, such as the addition of an ameliorant that can adsorb, complex, or coprecipitate trace elements (2-4). The treated soil could then be left in situ if the environmental conditions are suitable or disposed of safely in a landfill. Often it is easy to identify ameliorants for specific pollutants, but mixtures of pollutants may be more difficult to tackle. Common trace element pollutants are wood impregnation chemicals, such as copper $(\mathrm{Cu})$, chromium $(\mathrm{Cr})$, and arsenic (As) (CCA). In CCA-contaminated soils, the choice of ameliorant is limited for a number of reasons. For example, large $\mathrm{pH}$ fluctuations affect the mobilization of $\mathrm{Cu}$ and $\mathrm{As}$ in opposite ways and so should be avoided (5). Metallic iron (Fe)based ameliorants have been suggested for the remediation of As-contaminated soil because their oxidation does not influence $\mathrm{pH}$. The newly formed Fe oxides can effectively sorb As in soil and reduce its mobility, availability, and phytotoxicity (6-9).

This paper describes tests of a promising amelioration procedure using Fe-containing blaster sand (BS) or oxygenscarfing granulate (OSG) in a pilot-scale experiment and subsequent assessment of the stability of the treated soil to determine its most appropriate final destination. The stabilization technique was assessed with regard to the feasibility of mixing ameliorants at an industrial scale and the efficiency of the stabilization under different redox conditions. Two types of experiments were conducted: a field experiment, in which $i$ ) the mixing of the soil and ameliorant and ii) the stability of the target elements in the soil were investigated under natural conditions in $1-\mathrm{m}^{3}$ lysimeters; and a laboratory experiment to assess the stability of the elements under low redox conditions.

The investigation addressed 3 main issues: $i$ ) the mixing and homogenization of the treated soil, ii) the sustainability of the treatment over the long term, and iii) the feasibility of stabilization as a soil remediation method. Laboratory and field studies were conducted in parallel to assess the stability of the elements considered.

\section{MATERIAL AND METHODS}

In previous work, treatment with $\mathrm{Fe}$ grit $\left(\right.$ pure $\mathrm{Fe}^{0}$ ) was shown to significantly reduce the leaching of all target elements at the cumulative liquid-to-solid ratio of $10: 1$. The recorded reductions were $98 \%$ for $\mathrm{As}, 91 \%$ for $\mathrm{Cu}$, and $45 \%$ for $\mathrm{Cr}(5,10)$. The investigated soil was a sandy acidic soil (soil solution $\mathrm{pH}$ 4.6) highly contaminated with As (5904 mg kg$\left.{ }^{-1}\right), \mathrm{Cr}(3829 \mathrm{mg}$ $\mathrm{kg}^{-1}$ ), and $\mathrm{Cu}\left(1509 \mathrm{mg} \mathrm{kg}^{-1}\right)$, thus exceeding the generic guideline values for contaminated soils in Sweden by several orders of magnitude. Laboratory experiments also showed that other Fe products, for example OSG, could be a viable option for chemical stabilization.

\section{Soil and Amendment Characterization}

The soils were collected at 2 former wood impregnation sites in Northern Sweden: Forsmo (soil F) and Robertsfors (soil R) (Table 1). A complete description of the method is presented elsewhere $(11,12)$. 
Table 1. Main characteristics of the untreated soil $(n=3, \pm S D)(11,12)$.

$\mathrm{pH}\left(1: 2 \mathrm{ddH}_{2} \mathrm{O}\right)$

Electrical conductivity $\left(\mu \mathrm{S} \mathrm{cm}{ }^{-1}\right)$

Total solids (\%)

Loss on ignition (\%)

Organic carbon (\%)

Cation exchange capacity $\left(\mathrm{cmol} \mathrm{kg}^{-1}\right)$

Water-holding capacity (\%)

Texture

Sand (\%)

Silt (\%)

Clay (\%)

Elements (total concentration) ( $\mathrm{mg} \mathrm{kg}^{-1}$ dry weight)

Arsenic

Chromium

Copper

Zinc

Nickel

Manganese
$6.02 \pm 0.01$

$439 \pm 26$

$88.1 \pm 1.8$

$1.2 \pm 0.0$

$0.95 \pm 0.18$

$5.04 \pm 0.26$

39.8

Sandy loam

69.5

28.5

2.0

$310.1 \pm 17.4$

$62.8 \pm 10.8$

$15.5 \pm 0.2$

$132.6 \pm 6.7$

$11.6 \pm 0.2$

$330.6 \pm 15.6$
$5.75 \pm 0.03$

$721 \pm 3$

$87.4 \pm 0.1$

$4.8 \pm 0.1$

$3.13 \pm 0.05$

$11.6 \pm 0.3$

$53.1 \pm 0.2$

Loamy sand

77.6

21.4

1.0

$88.7 \pm 11.0$

$41.9 \pm 3.5$

$29.3 \pm 3.5$

$58.0 \pm 6.4$

$6.6 \pm 0.8$

$289.2 \pm 12.9$
Two by-products from the steel production industry were used for the stabilization: BS, $<1 \mathrm{~mm}$ diameter, containing $97 \%$ $\mathrm{Fe}^{0}$ with manganese $(\mathrm{Mn})(<1 \%)$ as the major impurity; and OSG, $<2 \mathrm{~mm}$ diameter, containing $79 \% \mathrm{Fe}_{\text {tot }}\left(28 \% \mathrm{Fe}^{0}\right.$ and $69 \% \mathrm{Fe}$ oxides) with $\mathrm{Cr}, \mathrm{Mn}, \mathrm{Ni}$, and $\mathrm{Cu}$ as the major impurities (11).

\section{Ameliorant Mixing}

The field experiments began in June 2005 and 2006, respectively, for soils $\mathrm{F}$ and $\mathrm{R}$. The aim was to evaluate the treatment technique on a large scale using BS and OSG. Forty tonnes of soil F, moistened to $\sim 50 \%$ of soil water-holding capacity (WHC), and 10 tonnes of soil R, moistened to $\sim 30 \%$ of soil WHC, were mixed with or without the Fe products. Three mixtures of each soil were prepared: 1 with $1 \%$ BS (by weight), 1 with $8 \%$ OSG (by weight), and 1 with no ameliorant. The mixing was undertaken in 2 stages for soil $\mathrm{F}$ (Fig. 1) using first a screener crusher ( $a$ and $b$ ) and then a rotating single-skin trommel (c). Soil R was mixed only with a screener crusher.

To evaluate the mixing processes, samples were taken during the mixing of soil $\mathrm{F}$, both after the screener crusher mixing (step 1) and after the rotating single-skin trommel treatment (step 2). After each mixing stage, heaps of the soil were spread out on an asphalt surface to a depth of $1-2 \mathrm{dm}$, and 10 soil cylinders were taken through the entire soil depth. The sample locations were distributed using a stratified randomized design (Fig. 2a). The samples were dried, sieved to $2 \mathrm{~mm}$, split into subsamples of $\sim 8 \mathrm{~g}$, crushed to a maximum diameter of $0.125 \mathrm{~mm}$, placed in a sample cup, and analyzed using a portable Niton 700 Series X-ray fluorescence spectroscope (Thermo Fisher Scientific, Waltham, MA).

\section{Stability Under Natural Conditions}

Lysimeters were used to simulate natural conditions. About 1.3 tonnes of each soil mixture (unamended, mixed with $1 \% \mathrm{BS}$, and mixed with $8 \%$ OSG) of both soils were placed in separate lysimeters ( 6 in total) that were monitored from August 2005 for soil F and August 2006 for soil R. The lysimeters were watered weekly with $40 \mathrm{~L}$ of water during 3 summer months (July, August, and September). Each lysimeter was equipped with 3 MacroRhizon soil moisture samplers (Eijkelkamp, Giesbeek, The Netherlands). Soil pore water samples were taken monthly, between July and October, and their contents of trace elements and $\mathrm{Fe}$ were analyzed as described below.

\section{Stability Under Reduced Conditions}

In order to simulate long-term events under a variety of conditions, small containers were used in a laboratory experiment. Soil F was first split by fractional shoveling (13). For each soil-Fe mixture, $\sim 40 \mathrm{~kg}$ of soil was homogenized in a concrete mixer for $15 \mathrm{~min}$ and, while rotating, mixed with a defined amount of $\mathrm{Fe}$ material: 1\%, 7\%, or $15 \%$ (by weight) OSG or either $0.1 \%$ or $1 \%$ (by weight) BS. Control samples, without amendments, were homogenized according to the same procedure.

Mixed and homogenized samples were moistened with distilled water to $50 \%$ of the water-holding capacity (WHC) and distributed in $15-\mathrm{L}$ containers (13 kg of soil in each), which were loosely covered to reduce evaporation. The water content was kept constant for $2 \mathrm{wk}$ and monitored by weighing the containers. The amount of water in the containers was then adjusted: half of the samples were fully saturated with water

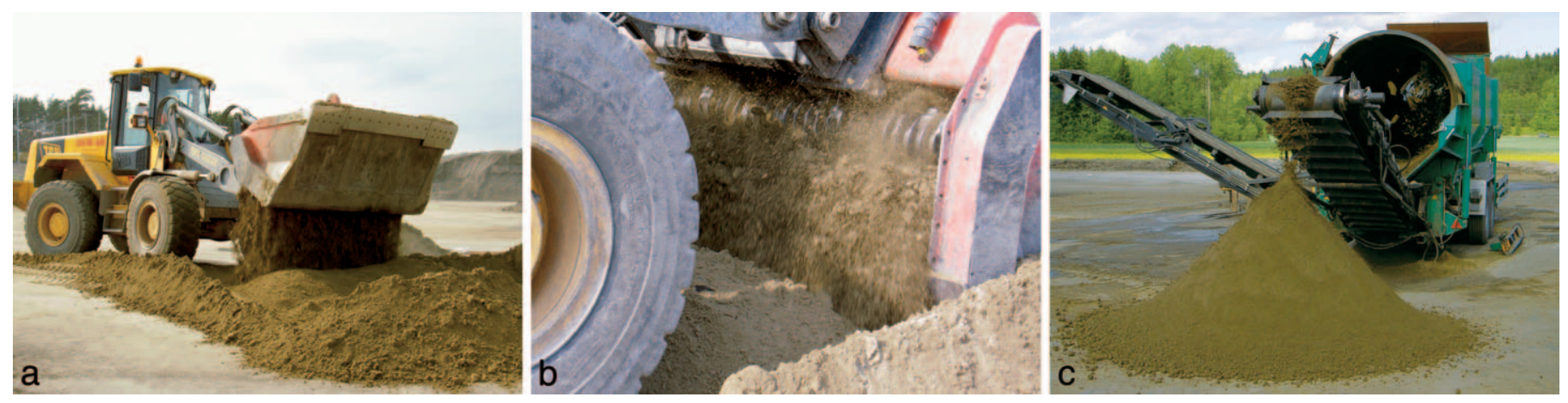

Figure 1. Mixing the ameliorant with the soil. Photo: S. Lidelöw. 

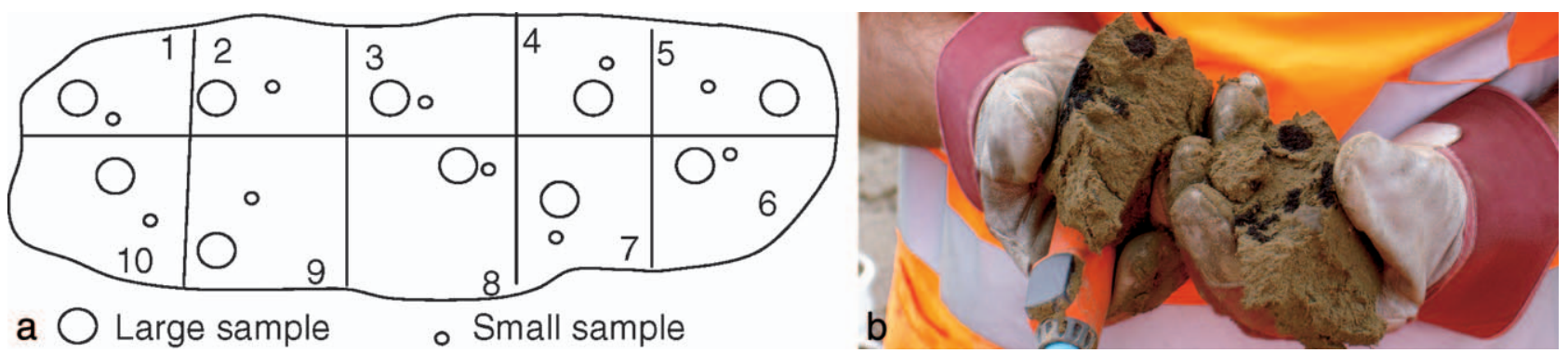

Figure 2. (a) Randomized soil sampling locations (b) and examples of soil samples after the first mixing stage. Photo: S. Lidelöw

(100\% WHC) and the other half kept at 50\% WHC, referred to as saturated and unsaturated samples, respectively. Three Rhizon soil moisture samplers were installed in each container.

\section{Assessing Treatment Efficiency by Pore Water Analysis and Leaching}

Four months later, samples of soil pore water were extracted into glass vacuum bottles. The bottles were frozen immediately and stored at $-20^{\circ} \mathrm{C}$ prior to analysis. The stability of the treatment was assessed as follows:

- Trace element content of pore water was analyzed by an inductively coupled plasma optical emission spectrometer (11).

- $\mathrm{As}{ }^{\mathrm{III}}$ and $\mathrm{As}{ }^{\mathrm{V}}$ in the pore water (11) were separated, identified, and quantified by ion chromatography followed by inductively coupled plasma mass spectrometry.

- The basal cytotoxicity of the pore water was assessed by assaying the growth inhibition of L929 cells using a neutral red incorporation (14) with some modification (11). We seeded 96-well microplates (Becton Dickinson Labware, Franklin Lakes, NJ) with 2500 cells per well and 10\% fetal calf serum as the growth medium. After filtration to achieve sterility $(0.22 \mu \mathrm{m}$; Millipore, Billerica, MA), 6 replicates of soil pore water were tested in a dilution series at 50\% (by volume) mixtures for $72 \mathrm{~h}$ before spectrophotometrically determining the optical density at $540 \mathrm{~nm}$ after the addition of neutral red.

Batch leaching tests of the treated soil in which soil was mixed with water acidified to $\mathrm{pH} 4$ with $1 \mathrm{M} \mathrm{HNO}_{3}$ at $\mathrm{L} / \mathrm{S} 10$ and agitated for $24 \mathrm{~h}$ using an end-over-end tumbler. The samples were filtered through a $0.45-\mu \mathrm{m}$ nitrocellulose membrane filter and immediately analyzed for trace elements by inductively coupled plasma optical emission spectrometer.

\section{RESULTS AND DISCUSSION}

\section{Mixing Quality}

Incorporation of the ameliorant into the soil is essential for the method to succeed. In situ applications are usually undertaken with traditional agricultural equipment, such as ploughs and harrows. However, if treatments are applied off-site, prior to reusing the soil or placing it in a landfill, other types of equipment can be used that are able to improve the soil and/or refine it, by dividing it into fractions of different quality classes that can be used for different purposes

The primary goal of the field experiment was to assess how well the Fe was distributed through the bulk soil. One measure of the mixing quality is the standard deviation of the average amendment concentration (15). Data from 10-dL samples of the $1 \% \mathrm{Fe}$ mix were evaluated. The standard deviation of the $\mathrm{Fe}$ content after mixing steps 1 and 2 had decreased significantly $(\alpha<0.05)$, correlating well with our visual assessment; after step
1 large clumps of Fe particles were observed (Fig. 2b), but they had disappeared after step 2. Arsenic showed the same tendency, but the difference was not statistically significant $(\alpha>0.05)$. Data are summarized in Table 2 .

Step 1 has a convective mixing effect, distributing the Fe particles through the bulk soil as small clusters, whereas step 2 breaks up the aggregations and spreads them more evenly through the bulk soil, corresponding to diffusive mixing. Step 2 alone would probably have been less efficient than the combined process, especially because segregation effects in tumbling mixers have been reported (15).

\section{Trace Element Stabilization Under Saturated and Unsaturated Conditions}

Both $\mathrm{Fe}$ and As are redox-sensitive elements, so their mobility is enhanced under anaerobic conditions (16-18). Therefore, our efforts focused on assessing the behavior of the treated soil under artificially created anaerobic conditions, that is, waterlogged soil. Even if waterlogging is unlikely to occur in a landfill, this allowed us to simulate the anaerobic conditions that develop due to the degradation of organic matter. Further, many former wood impregnation sites are situated close to rivers, and waterlogging may occur during floods.

In the unamended saturated samples of both soils, the As content of the pore water increased over time (Fig. 3). The arsenic concentration was 1-2 orders of magnitude higher in saturated than in unsaturated samples. Iron oxide is unstable in reduced environments, and both $\mathrm{Fe}$ and As occurred as reduced soluble species, that is, $\mathrm{Fe}^{\mathrm{II}}$ and $\mathrm{As}{ }^{\mathrm{III}}$. The soil amended with $17 \%$ OSG had arsenic concentrations 1-2 orders of magnitude lower than the control soil without ameliorants, indicating that a greater amount of $\mathrm{Fe}$ had a positive effect on As retention. A possible explanation for this finding is that some of the $\mathrm{Fe}$ oxide had not dissolved and adsorbed As. The Fe content in the pore water was about $0.6 \mathrm{~g} \mathrm{~L}^{-1}$ in all saturated samples (Fig. 4), whereas there was about $250 \mathrm{~g}$ OSG per liter of pore water, indicating that a large amount of the $\mathrm{Fe}$ was still available for adsorption.

Figure 4 shows pore water concentrations of redox-sensitive trace elements after the experiment had been running for 3 mo. The data show that water saturation, that is, the development of

\begin{tabular}{|c|c|c|c|c|c|}
\hline \multirow{2}{*}{$\begin{array}{l}\text { Treatment } \\
\text { step }\end{array}$} & \multirow{2}{*}{$\begin{array}{l}\text { Number of } \\
\text { samples }\end{array}$} & \multicolumn{2}{|c|}{$\begin{array}{c}\text { Average } \\
\text { concentration } \\
\left(\mathrm{mg} \mathrm{kg}^{-1}\right)\end{array}$} & \multicolumn{2}{|c|}{$\begin{array}{c}\text { SD } \\
\left(\mathrm{mg} \mathrm{kg}^{-1}\right)\end{array}$} \\
\hline & & $\mathrm{Fe}$ & $\mathrm{Fe}$ & $\mathrm{Fe}$ & As \\
\hline 1 & 10 & 21900 & 3020 & 3020 & 302 \\
\hline 2 & 10 & 23900 & 905 & 905 & 294 \\
\hline
\end{tabular}




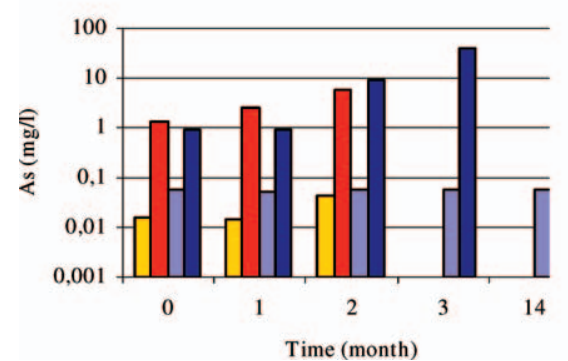

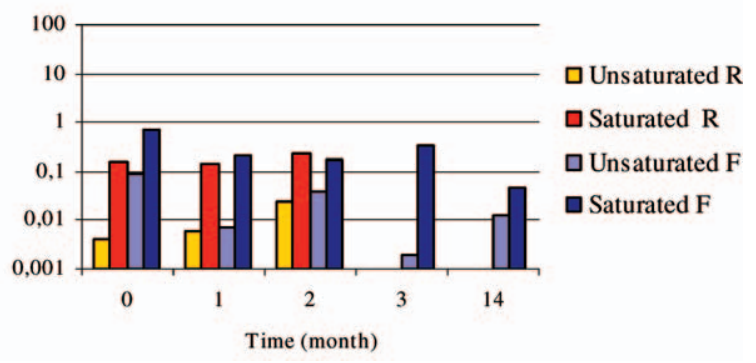

Figure 3. Changes in arsenic concentrations in the pore water of soils Robertsfors and Forsmo over time under saturated and unsaturated conditions. Results for unamended soil (a) and soil treated with $17 \%$ OSG (b) are presented. anaerobic conditions in the saturated soil, had a clear effect on the concentrations. The concentrations of $\mathrm{Fe}$ and $\mathrm{Mn}$ were several orders of magnitude higher in the saturated soils. Under unsaturated aerobic conditions, the As concentration decreased with increasing $\mathrm{Fe}$ concentration. However, the high OSG additions $(17 \%)$ resulted in order of magnitude increases in $\mathrm{Ni}$ and $\mathrm{Cu}$ leaching compared with the untreated soil (to $0.8 \mathrm{mg}$ $\mathrm{L}^{-1}$ and $0.16 \mathrm{mg} \mathrm{L}^{-1}$, respectively). Leaching of $\mathrm{Cr}$ was very low with both $1 \% \mathrm{Fe}$ and $17 \%$ OSG. Chromium is seldom a problem in such applications because its mobility is low (11). Leaching of zinc was not affected by any of the treatments.

Under anaerobic conditions, 17\% OSG reduced arsenic leaching by 2 orders of magnitude compared with the unamended saturated soil. Nickel and $\mathrm{Cu}$ leaching was very low because these elements are less soluble under anaerobic conditions.

The effect of BS was weaker than expected (3, 4) (Fig. 4), because metallic iron $\left(\mathrm{Fe}^{0}\right)$ was found to reduce arsenic leaching very efficiently in previous tests. Uneven mixing may explain the poor reduction in As concentration of the soil pore water, because, stochiometrically, $0.1 \% \mathrm{Fe}$ should have been sufficient. In addition, the BS particles were larger in this study than in previous ones, so less surface area was available for adsorption (19).

Oxygen-scarfing granulate seems to have potential as an ameliorant, even though 4 to 8 times more of the material than $\mathrm{BS}$ is required to achieve an equivalent effect. Amendment with $17 \%$ OSG decreased the mobility of As even when conditions were anaerobic, although stabilization was most efficient under aerobic conditions. Under aerobic conditions, the unwanted leaching of $\mathrm{Ni}$ and $\mathrm{Cu}$ could be a limiting factor, although these elements present no problems under anaerobic conditions.

The utility of L929 cells for assaying harmful levels of various metals (including As) in aqueous solutions has been demonstrated (20). The cytotoxicity decreased from almost $100 \%$ in the untreated soil to less than $10 \%$ (within the range of biological variation of the cells used in the bioassay in the absence of pore water) in the soil amended with $1 \%$ and $17 \%$.
An exponential correlation $\left(\mathrm{R}^{2}=85 \%\right)$ between cytotoxicity and the concentration of $\mathrm{As}^{\mathrm{III}}$ in the pore water was found. As ${ }^{\mathrm{III}}$ is more toxic than $\mathrm{As}^{\mathrm{V}}$ both with regard to acute toxicity (20) and genotoxicity (21). In the laboratory test, the concentration of $\mathrm{As}^{\mathrm{III}}$ decreased with increasing ameliorant concentrations (Fig. 5).

It should be noted that several factors may complicate the investigation of As speciation in soil $(22,23)$. Air intruding during sampling and the analysis of samples with low redox potentials may easily affect detected As levels, because (inter alia) $\mathrm{Fe}$ has a high propensity to oxidize and rapidly precipitate with As that may be bound to it. This may account for at least some of the large range of $\mathrm{As}^{\mathrm{III}}$ concentrations (spanning 2 orders of magnitude) recorded in the control triplicates. In support of this hypothesis, a brown precipitate was observed during the pore water sampling and sample preparation for speciation analysis, which was assumed to be precipitated $\mathrm{Fe}$ oxide onto which As adsorbs. The total As ${ }^{\mathrm{III}}$ concentration was probably underestimated. However, the mere presence of As ${ }^{\text {III }}$ is indicative of anaerobic conditions and illustrates the risk that As migration and toxicity may occur in anaerobic conditions that develop in landfills.

\section{Future Management of the Soil}

The laboratory experiments showed that the development of anaerobic conditions adversely affected the results of the treatments with respect to As mobility. Other trace elements present in the ameliorant may cause problems with increasing amendment concentrations. However, laboratory tests do not take into account large-scale effects, such as mixing, development of gradients, and climatic influences.

Arsenic (because of its toxicity) and dissolved Ni derived from the OSG were identified in the laboratory experiment as the most critical elements for the success of the treatment. Figure 6 shows the pore water concentrations of As and $\mathrm{Ni}$ in the lysimeters with each of the 3 mixture of soils $\mathrm{F}$ and $\mathrm{R}$ : unamended, with $1 \% \mathrm{BS}$, and with $8 \%$ OSG.

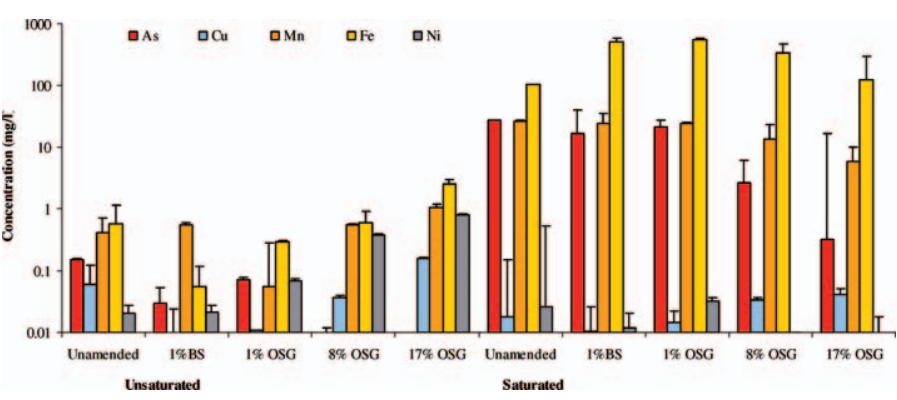

Figure 4. Concentrations of selected metals in the pore water of soil Forsmo after 2 mo in buckets at $50 \%$ water-holding capacity with different iron concentrations.

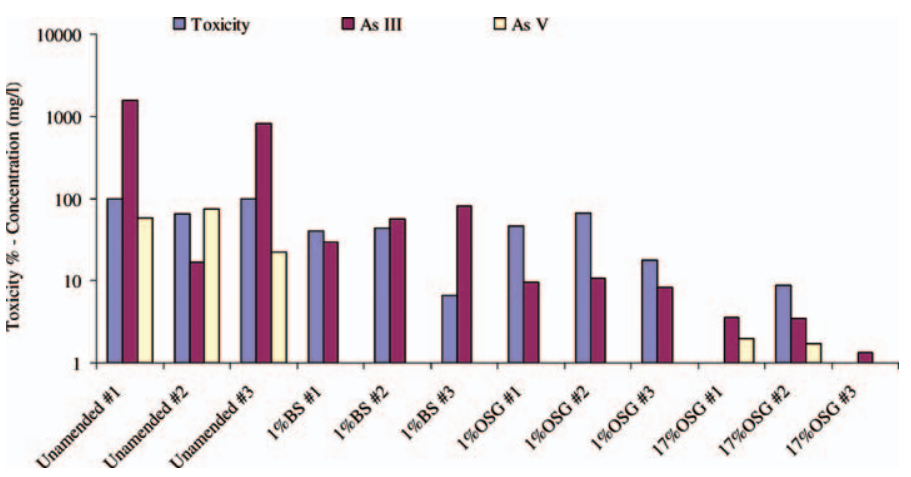

Figure 5. Arsenic speciation and toxicity of the pore water in the saturated soil samples according to amendment. 
O Untreated $\bullet 1 \%$ BS $\Delta 8 \%$ OSG

samples from the lysimeters $(n=3, \pm S D)$ with soils Forsmo (top) and Robertsfors (bottom).
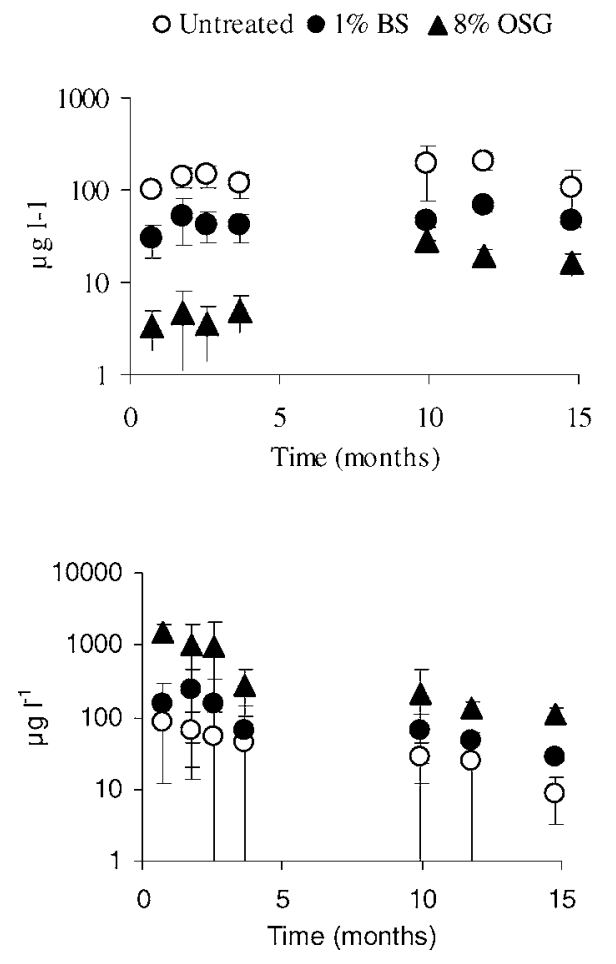
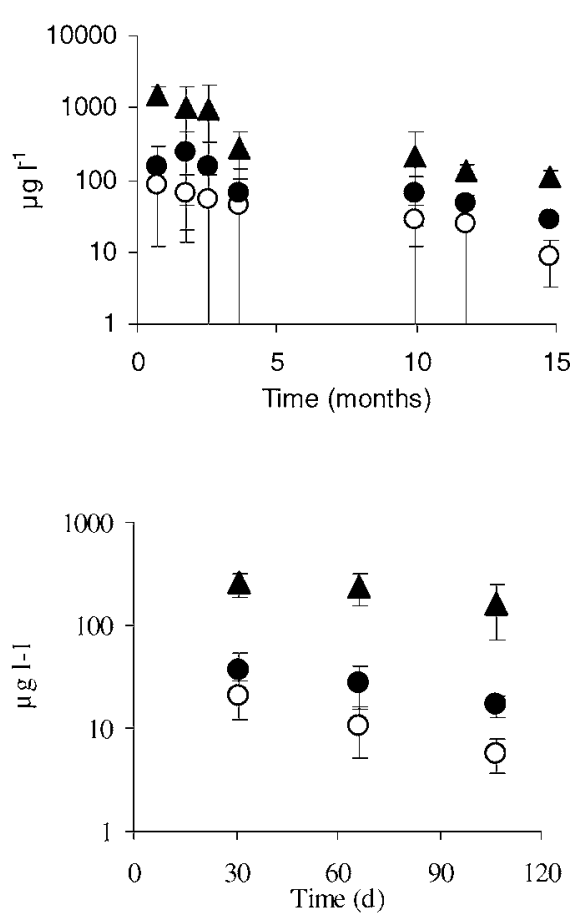

For soil $\mathrm{F}$, the As concentration in the pore water was lowest in the samples treated with $8 \%$ OSG, although the As concentration increased by almost an order of magnitude in these samples during the winter. The addition of $1 \%$ BS reduced As leaching by (on average) $70 \%$ and the levels of leached As after this treatment remained relatively stable over time. In soil $\mathrm{R}$, the additions had little effect on As mobility; the concentration was initially halved but returned to levels close to those of the untreated soil towards the end of the sampling period. Oxygen-scarfing granulate seems to lose its adsorptive capacity more rapidly in soil $\mathrm{R}$ than in soil $\mathrm{F}$ because the treatment efficiency of the OSG was significantly lowered after only 3 mo. This may be, at least partly, because the oxidation of Fe can limit its adsorptive capacity and the higher content of organic matter in soil $\mathrm{R}$ may enhance the development of anaerobic conditions. Further, soil $\mathrm{R}$ reportedly has a higher fraction than soil $\mathrm{F}$ of $\mathrm{As}^{\mathrm{III}}$, which has a lower affinity to $\mathrm{Fe}$ than $\mathrm{As}^{\mathrm{V}}$ (24).

For both soils, the highest Ni leaching was observed with the $8 \%$ OSG amendment (Fig. 6). The Ni concentration was higher in soil $\mathrm{F}$ than in soil $\mathrm{R}$ for both untreated and treated soils. This is probably an effect of the pore water $\mathrm{pH}$ being lower in soil $\mathrm{F}$ (5.3-6.3) than in soil R (6.8-7.5) (11), because Ni solubility is closely linked to $\mathrm{pH}$.

The lysimeters model the upper layer of the soil profile, which could be the surface of a stabilized site or a landfill cover, where treated soil could be used in the protection layer. For such applications, metallic Fe, such as BS, may be recommended to avoid addition of other trace elements, such as $\mathrm{Ni}$, to the soil. However, the addition of an ameliorant at more than $1 \%$ may be necessary to enhance the stabilization, because the effects observed in the lysimeters were weaker than expected.

As in the laboratory experiment, increased $\mathrm{Cu}$ leaching from soil $\mathrm{F}$ was observed after treatment with the OSG. In soil R, however, $\mathrm{Cu}$ leaching decreased by an order of magnitude after addition of OSG. As for $\mathrm{Ni}$, this difference between the soils may be attributed to the differences in their pore water $\mathrm{pH}$. Zinc and $\mathrm{Cr}$ leaching from soils $\mathrm{F}$ and $\mathrm{R}$ decreased by $\sim 80 \%-90 \%$ with additions of either $1 \%$ BS or $8 \%$ OSG. For soil $\mathrm{F}$, the treatment efficiency was slightly higher for $8 \%$ OSG than for $1 \%$ BS (11).

Excavated soil is classified as waste (25) and, therefore, must be assessed according to waste assessment rules, such as European Union acceptance criteria for landfilling of waste (NFS 23004:10) (26), which are based on the mobile fraction of the elements, measured by batch leaching tests. The results from batch leaching tests of amended and unamended soil from the saturated and unsaturated containers are presented in Figure 7.

The batch leaching tests did not reflect the conditions observed in either the laboratory or the field tests (27). In the leaching test, leached As concentrations were low $\left(<1 \mathrm{mg} \mathrm{kg}^{-1}\right)$ in samples from the saturated buckets with high Fe concentrations (Fig. 7), whereas the As concentration in the pore water was an order of magnitude higher. This may have been due to dissolved $\mathrm{Fe}$ and As precipitating during the leaching and subsequent filtration procedures, both of which are performed under aerobic conditions. According to the leaching tests, soil treated with $1 \% \mathrm{Fe}$ or more fulfills the criteria for disposal in landfill at a site for inert waste, that is, $<0.5 \mathrm{mg} \mathrm{kg}^{-1}$ As was leached (26). However, the pore water colleted from the same soils contained the highest As concentrations, such as up to 20

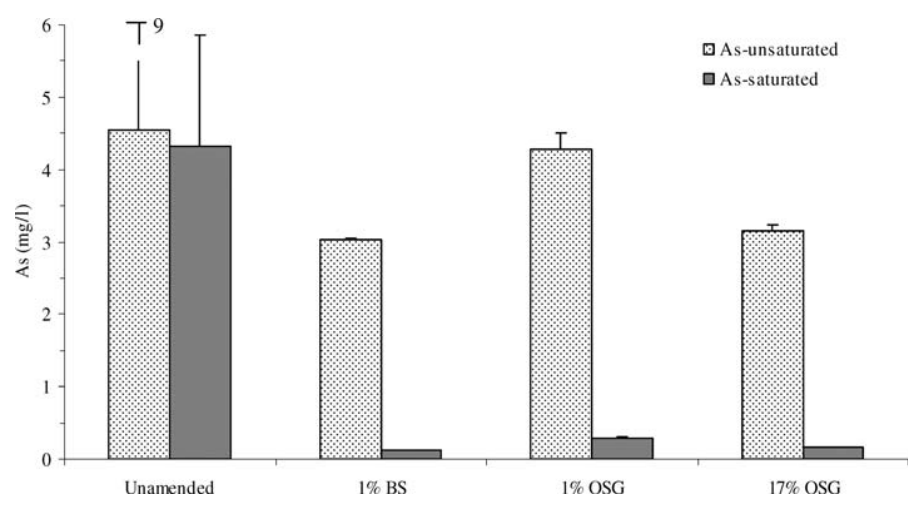

Figure 7. Results from batch compliance leaching tests at L/S 10 using soil Forsmo from the laboratory test. 
$\mathrm{mg} \mathrm{L}^{-1}$ for the soil amended with $1 \% \mathrm{BS}$. The batch leaching tests do not take into account the effect of reduced conditions and, hence, underestimate As leaching under anaerobic conditions $(4,12,17,28)$. Microorganisms may play an active role in As reduction $(18,29)$, and this is not taken into account in 1-d-long leaching tests. The relevance of batch leaching tests to assess the behavior of redox-sensitive elements, such as $\mathrm{Fe}$ and $\mathrm{As}$, in the landfill environment is, therefore, questionable (28).

\section{CONCLUDING REMARKS}

The treatments with high additions of ameliorant were more successful in both the laboratory and the field experiments, even though there was enough Fe stochiometrically to bind all As in all mixtures even at the lowest addition rates. This is probably because more soil particles came into contact with Fe particles at the higher concentrations. The results also indicate that increases in Fe particle sizes are likely to reduce the efficiency of the stabilization treatment and corroborate the known importance of mixing in treatments for contaminated soil.

The results presented in this study indicate that the development of anaerobic conditions, simulated by water saturation, increases the fraction of $\mathrm{As}^{\mathrm{III}}$ and, consequently, As mobility. Furthermore, increasing the amount of ameliorant is not always an acceptable option because it increases, rather than decreases, the concentration of certain trace elements that may cause problems. The use of $17 \%$ OSG, for example, had drawbacks, such as increasing the concentrations of $\mathrm{Ni}$ in the pore water. The final destination of the treated soil should govern the amendment choice; for example, an OSG concentration of $\sim 10 \%$ may be suitable if the soil is to be landfilled under anaerobic conditions. In such cases, lower As leaching was observed compared with the untreated soil, even though the measured concentrations were 2 orders of magnitude higher than in the unsaturated aerobic soil. In addition, $\mathrm{Ni}$ and $\mathrm{Cu}$ leaching were not critical under anaerobic conditions.

Alternatively, the soil could be kept under aerobic conditions, if used as a cover material at landfills or in situ at brownfield sites, for example. In such cases, BS would be a better option than OSG, because $\mathrm{Ni}$ and $\mathrm{Cu}$ concentrations were not of concern with $1 \%$ BS. In addition, the treatment appeared to produce better effects in the long term if BS was used rather than OSG. However, although earlier experiments with $1 \% \mathrm{Fe}^{0}$ have shown high treatment efficiency, full-scale treatment requires higher addition rates because of the difficulty in achieving good levels of mixing when adding small amounts of Fe to the bulk soil.

The toxicity assessment and the speciation of As analysis highlighted the risks associated with the development of anaerobic conditions and the leaching of $\mathrm{As}^{\mathrm{III}}$ in such environments as landfills and flooded areas. Further, limitations of the standard leaching tests to simulate the conditions that developed in the saturated soil were demonstrated, and the project showed that placing As-contaminated soil in landfill may have unexpected effects.

\section{FURTHER RESEARCH}

Further research should continue to focus on the sustainability of the treatment by investigating the long-term efficiency of OSG under anaerobic conditions and the effect of the soil quality, that is, organic content, on the treatment efficiency.
Thorough mixing is essential for the success of any such treatment, and the factors affecting the mixing efficiency should be investigated, for instance by assessing the effects of other types of mixer and developing indices to describe the degree of mixing. In addition, monitoring should be conducted over longer periods, and toxicity assays could be developed to determine genotoxicity both in vitro and in vivo.

\section{References and Notes}

1. Wang, S. and Mulligan, C.N. 2006. Natural attenuation process for remediation of arsenic contaminated soils and groundwater. J. Hazard. Mater. B138, 459-470.

2. Mench, M., Vangronsveld, J., Clijsters, H., Lepp, N.W. and Edwards, R. 2000. In situ metal immobilisation and phytostabilisation of contaminated soils. In: Phytoremediation of Contaminated Soil and Water. Norman, T. and Banuelos, G. (eds). Lewis Publishers, Boca Raton, pp. 323-358.

3. Kumpiene, J. 2005. Assessment of Trace Element Stabilization in Soil. PhD Thesis, Luleå University of Technology, Luleả, Sweden.

4. Tokunaga, S. and Hakuta, T. 2002. Acid washing and stabilization of an artificial arsenic-contaminated soil. Chemosphere 46, 31-38.

5. Kumpiene, J. Castillo Montesinos, I, Lagerkvist, A and Maurice, C. 2006. Evaluation of the critical factors controlling stability of chromium, copper, arsenic and zinc in irontreated soil. Chemosphere 67, 410-417.

6. Jain, A., Raven, K.P. and Loeppert, R.H. 1999. Arsenite and arsenate adsorption on ferrihydrite: surface charge reduction and net $\mathrm{OH}^{-}$release stoichiometry. Environ. Sci. Technol. 33, 1179-1184

Mench, M., Bussiere, S., Boisson, J., Castaing, E., Vangronsveld, J., Ruttents, A., De Koe, T., Bleeker, P., et al. 2003. Progress in remediation and revegetation of the barren Jales gold mine spoil after in situ treatment. Plant Soil 249, 187-202.

Warren, G.P. Alloway, B.J., Lepp, N.W., Singh, B., Bochereau, F.J.M. and Penny, C. 2003. Field trials to assess the uptake of arsenic by vegetables from contaminated soils and soil remediation with iron oxides. Sci. Tot. Environ. 311, 19-33.

9. Warren, G.P. and Alloway, B.J. 2003. Reduction of arsenic uptake by lettuce with ferrous sulfate applied to contaminated soil. J. Environ. Oual. 32, 767-772.

10. Kumpiene, J., Ore, S., Renella, G., Mench, M. Lagerkvist, A and Maurice, C. 2006 Assessment of zerovalent iron for stabilisation of $\mathrm{Cr}, \mathrm{Cu}$ As in soil. Environ. Pollut. 144 $62-69$

11. Lidelöw, S., Ragnvaldsson, D., Tesfalidet, S. and Maurice, C. Field trials to assess the use of iron-bearing industrial by-products for stabilisation of CCA-contaminated soil Submitted to Sci. Tot. Environ. (In press).

2. Maurice, C., Gustavsson, B., Kumpiene, J. and Lidelöw, S. 2005. Stabilization of $C C A-$ Contaminated Soil with Iron Products: A Field Experiment. Kalmar Eco-Tech '05. 28-29 November 2005, Kalmar, Sweden. pp. 395-404.

13. Pitard, F.F. 1993. Pierre Gy's Sampling Theory and Sampling Practice: Heterogeneity, Sampling Correctness, and Statistical Process Control. CRC Press, Boca Raton, 448 pp.

14. Sauvant, M.P., Pepin, D., Bohatier, J., Groliere, C A and Guillot, J. 1997. Toxicity assessment of 16 inorganic environmental pollutants by six bioassays. Ecotoxicol. Environ. Saf. 37, 131-140.

15. Weinekötter, R. and Gericke, H. 2000. Mixing of Solids. Kluwer Academic Publishers, Delft, 154 pp.

16. Keimowitz A.R. Simpson, H.J., Stute, M., Datta, S., Chillrud, S.N., Ross, J. and Tsang, M. 2005. Naturally occurring arsenic: mobilization at a landfill in Maine and implications for remediation. Appl. Geochem. 20, 1985-2002.

17. Chatain, V., Sanchez, F., Bayard, R., Moszkowicz, P. and Gourdon, R. 2005. Effect of experimentally induced reducing conditions on the mobility of arsenic from a mining soil. J. Hazard. Mater. B1222, 119-128.

8. Chatain, V., Bayard, R., Sanchez, F., Moszkowicz, P. and Gourdon, R. 2005. Effect of indigenous bacterial activity on arsenic mobilization under anaerobic conditions. Environ. Int. 31, 221-226.

19. Lidelöw, S. and Maurice, C. 2006. Management of iron stabilised CC-contaminated soil. WASCON 2006, Sixth International Conference on the Environmental and Technical Implications of Construction with Alternative Materials: Science and Engineering of Recycling for Environmental Protection. Belgrade, Serbia, and Montenegro, pp. 665-676.

20. Fischer, A.B., Buchet, J.P. and Lauwerys, R.R. 1985. Arsenic uptake, cytotoxicity and detoxification studied in mammalian cells in culture. Arch. Toxicol. 57, 168-172.

21. Moore, M.M., Harrington-Brock, K. and Doerr, C.L. 1997. Relative genotoxic potency of arsenic and its methylated metabolites. Mutat. Res. 386, 279-290.

22. Wenzel, W.W., Kirchbaumer, N., Prohaska, T., Stingeder, G., Lombi, E. and Adriano, D.C. 2001. Arsenic fractionation in soils using an improved sequential extraction procedure. Anal. Chim. Acta 436, 309-323.

23. Hudson-Edwards, K.A., Houghton, S.L. and Osborn, A. 2004. Extraction and analysis of arsenic in soils and sediments. Trends Anal. Chem. 23, 745-752.

24. Ragnvaldsson, D. Hazard Screening of Contaminated Sites-Bioavailable Fractions and Biological In Vitro Tools. PhD Thesis, Umeå University, Umeå, Sweden.

25. Lidelöw, S 2004. Environmental Assessment of Secondary Construction Material. Licentiate Thesis. Luleå University of Technology, Luleå, Sweden.

26. European Commission. 2002. Council Decision Establishing Criteria and Procedures for the Acceptance of Waste at Landfills Pursuant to Article 16 and Annex II of Directive 1999/31/EC. Document 14473 ENV 682. Council of the European Union, Brussels, 22 pp.

27. Hartley, W., Edwards, R. and Lepp, N.W. 2004 Arsenic and heavy metal mobility in iron oxide-amended contaminated soils as evaluated by short- and long-term leaching tests. Environ. Pollut. 131, 495-504.

28. Ghosh, A., Mukiibi, M. and Ela, W. 2004. TCLP underestimates leaching of arsenic from solid residuals under landfill conditions. Environ. Sci. Technol. 38, 4677-4682.

29. Yamamura, S., Yamamoto, N., Ike, M. and Fujita, M. 2005. Arsenic extraction from solid phase using a dissimilatory arsenate-reducing bacterium. J. Biosci. Bioeng. 100, 219-222.

30. Acknowledgments: This work was financially supported by European Union Structural Funds and New Objective 1, North Sweden Soil Remediation Center (MarksaneringsCentrum Norr - MCN), contract no. 113-12534-00, and performed in cooperation with Ragn-Sells Avfallsbehandling AB. Thanks are extended to technicians at Lulea University of Technology and the Ragn-Sells and Nordmarks Miljö facilities. 
Christian Maurice has a PhD in the field of waste technology and works in the field of landfill technology, soil sampling, and soil treatment. $\mathrm{He}$ is active within the Northern Sweden Soil Remediation Center. He now works as a consultant in environmental engineering at Ramböll Sweden and as a parttime research associate at Luleå University of Technology. His address: Ramböll, P.O. Box 850, SE-971 26 Luleå, Sweden. E-mail: christian.maurice@ ramboll.se

Sofia Lidelöw is a PhD student in waste science and technology at Luleå University of Technology. She works with the environmental implications of using industrial by-products in construction applications, such as fill, roadbase, and landfill covering. Her address: Luleå University of Technology, SE-971 87 Luleå, Sweden.

E-mail: sofia.lidelow@Itu.se

Björn Gustavsson is a $\mathrm{PhD}$ student in waste science and technology at Luleå University of Technology. He works with the theory of sampling (TOS) and TOS applications to contaminated soil. His address: Luleå University of Technology, SE-971 87 Luleå, Sweden.

E-mail: bjorn.gustavsson@Itu.se

Anders Lättström is a PhD student at Umeå University. He is studying arsenic speciation in CCA-contaminated soils and effects of stabilization techniques. He is also studying the stability and transition of arsenic species during sample preparation and storage. His address: Department of Chemistry, Umeå University, SE-901 87 Umeå, Sweden.

E-mail: anders.lattstrom@ @ chem.umu.se

Daniel Ragnvaldsson is a PhD student at the Swedish Defence Research Agency and has a MSc in chemistry with a focus on environmental chemistry and toxicology. At present he works in Umeå within the Northern Sweden Soil Remediation Center (MCN) developing toxicological screening tools for hazard assessment of polluted sites. His address: Swedish Defence
Research Agency (FOI), Department of Threat Assessment, Toxicology, SE-901 82, Umeå, Sweden.

E-mail: daniel.ragnvaldsson@foi.se

Dr. Per Leffler is a senior research officer at the Swedish Defence Research Institute in Umeå. His experience in the laboratory sciences of general toxicology, metal toxicology, cell culturing, multivariate experimental design, and sampling in the field is well suited for all implications of operational toxicology. His address: Swedish Defence Research Agency (FOI), Department of Threat Assessment, Toxicology, SE-901 82, Umeå, Sweden.

E-mail: per.leffler@foi.se

Dr. Lars Lövgren is an associate professor in inorganic chemistry at Umeå University. His research is focused on sorption processes at mineral/water interfaces. Most of his research projects have dealt with problems related to mining waste deposits and contaminated soils. His address: Department of Chemistry, Umeå University, SE-901 87 Umeå, Sweden.

E-mail: lars.lovgren@chem.umu.se

Dr. Solomon Tesfalidet is an analytical chemist from the Department of Chemistry at Umeå University, where he works as a senior lecturer and researcher. His research area deals with speciation analysis of trace elements in environmental and biological samples using species-specific isotope dilution and combination of chromatographic and spectrophotometric techniques. His address: Department of Chemistry, Umeå University, SE-901 87 Umeå, Sweden.

E-mail: solomon.tesfalidet@chem.umu.se

Dr. Jurate Kumpiene, researcher at the Division of Waste Science and Technology, Luleå University of Technology, has been working for several years on soil stabilization techniques and methods for determining soil stability. Her address: Luleå University of Technology, SE-971 87 Luleå, Sweden.

E-mail: jurate.kumpiene@Itu.se 